\title{
Yogur bajo en calorías añadido con harina de yacón: desarrollo y evaluación físico-química
}

\author{
Low-calorie yogurt added with yacon flour: \\ development and physicochemical evaluation
}

\begin{abstract}
Yacon flour has been used in several food products due to its high fructooligosaccharides and inulin contents, compounds that present health promoting properties. In this study, yacon flour was used as an ingredient in light yogurt in the following concentrations: $1.58 ; 2.56 ; 3.00$ and $3.86 \%$. Centesimal composition, $\mathrm{pH}$, soluble solids, acidity and apparent viscosity of the yogurt supplemented with yacon were determined. Results were evaluated through analyses of variance and regression. Centesimal composition of the yogurts allowed for their classification as low-fat foods, presenting low carbohydrate content and containing dietary fiber, especially those supplemented with more than $2.56 \%$ yacon flour, which may be considered as sources of fiber and, consequently, prebiotics. Physicochemical analysis revealed significant $(p<0.05)$ changes in analysis of color, soluble solids, acidity and viscosity at the temperatures of 10 and $25{ }^{\circ} \mathrm{C}$ with the increase in yacon flour.

Key words: fructooligosaccharides, inulin, prebiotics, yogurt, yacon.
\end{abstract}

\section{INTRODUCTION}

A growing concern regarding health and quality of life is causing people to value physical exercise, eating healthier foods and reducing consumption of those high in sugar, salt and fat. The main cause for this change in lifestyle and eating habits is a constant search for health, which assures a better quality of life and prevents diseases (1).

Parallel to this, there has been a rapid development in foods which present not only nutritional characteristics and proper technology, but also ingredients that have a biological role in preventing diseases and promoting health, known as functional foods (2).

Among functional food, one group that can be highlighted is prebiotics, which are non-digestible components, usually oligosaccharides, with bifidogenic effects capable of stimulating growth and/or the activity of some of the bacteria present in the intestine (3).

Yacon (Smallanthus sonchifolius, Polymnia sonchifolia Poepp. \& Endl. or Polymnia edulis Wedd -4) is a root found in the Andean region known for its high concentration of fructooligosaccharides (FOS), a special kind of carbohydrate with beneficial attributes to human health. One of the main characteristics of such carbohydrates is their ability to stimulate the growth of non-pathogenic bacteria through colonic fermentation, which causes them to be classified as bioactive
Christiane Mileib Vasconcelos Valéria Paula Rodrigues Minim José Benício Paes Chaves

Food Technology Department, Federal University of Viçosa Viçosa, Minas Gerais. Brasil

Corresponding author: Profeso

osé Benício Paes Chaves Food Technology Department Federal University of Viçosa /UFV Av. P.H. Rolfs s/n, 36570-000 Viçosa, Minas Gerais, Brazil.

Tel.: +55 3138992230 Fax: +553138992208

E-mails: chrismileib@yahoo.com.br,vprm@ufv.br, jbchaves@ufv.br

Este trabajo fue recibido el 15 de Mayo de 2012 y aceptado para ser publicado el 20 de Julio de 2012

components with claimed prebiotic effects (5), and consequently, functional foods.

Because of the nutritional benefits presented by yacon, its flour has been developed and used as an ingredient in some foods. This allows scientists to formulate products with low fat content, low caloric value and a high concentration of dietary fiber, especially FOS, which may provide a protective effect to customer health (6).

In Brazil, the addition of yacon flour is reported mainly as an ingredient in cereal-based products, such as cakes, "Champurrada" type biscuits, snacks and breads $(6,7)$. No application of this product is found whatsoever in drinks, since milk-based products are easily consumed and versatile with high physiological functionality, and also viewed as healthy products among consumers.

Development of light yogurt supplemented with yacon flour may be a good alternative in the fermented food market, allowing the preparation of a drink with prebiotic claims due to its high soluble dietary fiber content (especially FOS) for aiding in the functioning the intestinal tract, regardless of consumer age. The product may also contribute to reduce toxic metabolites and plasmatic cholesterol, improve mineral bioavailability, such as calcium, magnesium and phosphorus, contribute to the growth of bifidobacterium inside the colon, and also help in reduction of blood pressure (8). 
Based on these facts, the objective of the present study was to use different proportions of yacon flour as an ingredient in the preparation of light yogurts followed by evaluation of its effect on the physicochemical properties of the product.

\section{MATERIAL AND METHODS}

Experimental planning

Preparation of yogurts was conducted according to a completely randomized design, with four formulations and one control, in two repetitions. Four different concentrations of yacon flour were added to the yogurt prepared from skim milk and sweetened with aspartame (0.072 \%). The yacon flour concentration was estimated according to the quantity of dietary fiber, FOS and/or inulin recommended by the ANVISA (National Agency for Sanitary Surveillance) (9) for liquid food with claims of functional properties. This estimate was based on yacon flour centesimal composition. Thus, yacon flour was added to the yogurts at concentrations of $1.58,2.56,3.00$ and $3.86 \%$. These values are calculated to provide $1.50 \mathrm{~g}$ total fiber; $1.50 \mathrm{~g}$ of FOS and inulin; $1.75 \mathrm{~g}$ of FOS and inulin; and $1.50 \mathrm{~g}$ FOS per serving of yogurt, respectively. The yogurt serving size was set to be $200 \mathrm{~mL}$. The control yogurt consisted of a basic mixture of skim milk sweetened with aspartame, without addition of yacon flour.

\section{Production of yacon flour}

Yacon flour was produced according to the methodology described in Ribeiro (10), being obtained from $45.5 \mathrm{~kg}$ of yacon roots "in nature" which were purchased at the Belo Horizonte, MG vegetable market, between August and September 2009. The roots were manually peeled, sliced in a Walita RI7625 food processor and submersed, first, for 15 minutes in stainless steel bowls containing a sodium hypochlorite solution (4 to $6 \%$ active chlorine) at $200 \mu \mathrm{L} / \mathrm{L}$, and then into another stainless steel bowl containing a sodium bisulfite solution at $0.1 \%$ of the peeled root weight. Later, the sliced roots were dried in forced air ovens (Nova Ética $400 \mathrm{ND} / 300^{\circ} \mathrm{C}$, Vargem Grande Paulista, Brasil) at $55^{\circ} \mathrm{C}$ for $48 \mathrm{~h}$. The sliced dried roots were then ground in a vertical rotor fixed hammer mill (Marconi MA-090/CF, Piracicaba, Brasil) to obtain the flour, which was packed into polyethylene sacks and stored at $2-4{ }^{\circ} \mathrm{C}$.

\section{Process for production of light yogurt added with yacon}

Yacon flour and aspartame were added to skim milk and mixing was performed in a shaker (Omni Macro ES Digital Programmable Homogenizer, Kennesaw, USA) at 4,480 x g for $10 \mathrm{~min}$ and then heated to $83{ }^{\circ} \mathrm{C}$ and maintained at this temperature for $30 \mathrm{~min}$ inside a $20 \mathrm{~L}$ stainless steel yoghurt maker (Biasinox, Lambari, Brasil). This mixture was than cooled to $42{ }^{\circ} \mathrm{C}$ and supplemented with $0.02 \%$ concentrated freezedried, DVS type lactic acid bacteria containing Lactobacillus delbrüeckii subsp. bulgaricus and Streptococcus thermophilus (Christian Hansen, Valinhos, Brasil).

Milk fermentation occurred for about $6 \mathrm{~h}$ at $42-43{ }^{\circ} \mathrm{C}$ until the yogurt reached acidity values of $0.70-0.75 \%$ (in $\%$ of lactic acid). The yogurt was then cooled to $37^{\circ} \mathrm{C}$, submitted to curd breaking and then immediately packed in $860 \mathrm{~mL}$ polyethylene packages. The packages were stored at $2-4^{\circ} \mathrm{C}$ until the time of analysis, for a total of 30 days. Each yogurt formulation, control and the four different levels of yacon flour, was produced in two separate runs (replication).

\section{Determination of the centesimal} composition of the yogurts

The following analyses were performed: water content, via the gravimetric analysis (method 935.29 of AOAC, 11); protein, via the micro-Kjeldahl method (method 991.20 of AOAC, 11); lipids, via direct extraction in Soxhlet (method 963.15 of AOAC, 11) and ash via incineration (method 923.03 of AOAC, 11). Total dietary fiber (TDF) content was determined by summing soluble dietary fiber (SDF), insoluble dietary fiber (IDF), FOS and inulin contents. All measurements were made in duplicate.

The SDF and IDF contents were determined using a total

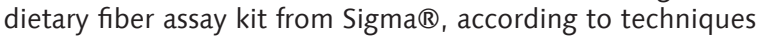
established by the AOAC (12), which are based on enzymaticgravimetric analyses. Results were reported as the average of duplicates for each experimental yogurt unit.

Determination of FOS and inulin were carried out according to the method reported by Kaneko et al. (13) using high performance liquid chromatography (HLPC) with the HPX 87P column from BIO-RAD (lead stationary phase) (California, USA), with purified water as the mobile phase. Samples were injected into the HPX 87P column coupled to a Pró-Star 410 liquid chromatograph from Varian with refraction index detector and an automatic injector (Auto Samples 410), with a flow rate of $0.6 \mathrm{~mL} / \mathrm{m}$ and column temperature of $85^{\circ} \mathrm{C}$, projecting a sequence of peaks that were compared to the standards.

The carbohydrate fraction was determined to be the remaining portion of the sample after discounting the levels of water, protein, lipid, ash and total dietary fiber.

\section{Determination of the caloric value of the yogurts}

The caloric value of the yogurt was calculated by using the Atwater coefficients, which consider $4 \mathrm{kcal} / \mathrm{g}$ for proteins and carbohydrates and $9 \mathrm{kcal} / \mathrm{g}$ for lipids (14).

\section{Determination of Lab color values of the yogurts}

Lab color coordinates were determined by a CR-10 color reader from Konica Minolta with the following operating conditions: CIE D65 illuminator (natural daylight), set at an angle of $8^{\circ}$ and $\mathrm{a} \mathrm{CIE} 10^{\circ}$ standard observer. The colorimeter directly supplied the $L^{*}$ (luminosity), $a^{*}$ and $b^{*}$ color values. The parameter $a^{*}$ takes positive values for reddish colors and negative values for the greenish ones, whereas $b^{*}$ takes positive values for yellowish colors and negative values for the bluish ones (15).

The calculation was obtained from two readings for each run, with the yogurt sample being put inside a $4 \mathrm{~mL}$ polystyrene cuvette, and between readings the cuvettes were washed with distilled water.

\section{Determination of $\mathrm{pH}$ of the yogurts}

The determination of $\mathrm{pH}$ was made according to the 017/IV method described by the Adolfo Lutz Institute (16) through direct reading with a digital pH meter (Tekna T-1000, São Bernardo do Campo, Brasil) using a $10 \mathrm{~mL}$ yogurt sample from each experimental unit.

\section{Determination of total soluble solids}

Total soluble solid values were measured directly in a bench-top $A B B E$ refractometer (São Paulo, Brasil) at temperature of $20 \pm 3^{\circ} \mathrm{C}$, with results given in ${ }^{\circ}$ Brix according to the analytical rules of the Adolfo Lutz Institute (16). 
Determination of acidity of the yogurts

The acidity was measured according to the 427/IV method described by the Adolfo Lutz Institute (16), through titration with a Dornic solution ( $\mathrm{NaOH} \mathrm{N} / 9$ ) and expressed in ${ }^{\circ}$ Dornic, where $0.1 \mathrm{~mL}$ of the $\mathrm{NaOH} \mathrm{N} / 9$ represents $1^{\circ} \mathrm{D}$.

Determination of apparent viscosity of the yogurts

Apparent viscosity was determined with a Searle type pipe rheometer from Brookfield, model R/S plus SST 2000, equipped with the Rheo 2000 software, produced by Brookfield Engineering Laboratories, Inc., USA. Measurements were made at $10{ }^{\circ} \mathrm{C}$ and $25^{\circ} \mathrm{C}$. These are temperatures of typical yogurt consumption and the general oral temperature (17). The measuring system adopted utilized the DG DIN sensor, with deforming rate of $10 \mathrm{~s}-1$. This experiment lasted for 2 minutes and generated a total of 30 points. Results were expressed in mPa.s.

\section{Statistical analysis}

Results of physicochemical determinations were analyzed in a completely randomized design (CRD) (18) model, with 5 yogurt formulations and 2 repetitions. The effect of yacon flour supplementation was evaluated via regression analysis, in which linear and quadratic effects were tested according to changes in the concentration of yacon flour in the yogurt.

The SAS (Statistical Analysis System - SAS Institute Inc., North Carolina, USA, (19), licenced to the Universidade Federal de Viçosa - UFV (Federal University of Viçosa) was used.

\section{RESULTS AND DISCUSSION}

Centesimal composition of the yogurt

Results of the centesimal composition of the yogurts are given in table 1.

Protein and lipid contents presented no significant variation ( $p>0.01)$ among the yogurts supplemented with yacon flour. This was expected since the yacon root has low concentrations of these compounds (4). This indicates the little influence that yacon may have on yogurt composition when used as an ingredient.

Protein content of the yogurts was between 3 and $4 \%$. This is in agreement with Brazilian regulations that demand a minimum of $2.9 \%$ (20). Lipid content was lower than 0.5 $\%$ so that the yogurt in the present study could be classified as a low fat product according to the 29th ordinance (21), and in conformance with GMC 47/97, it was classified as a skimmed yogurt (20).

With regards to water, ash, IDF, SDF, FOS, inulin and carbohydrate contents, the addition of different levels of yacon flour resulted in significant changes $(p<0.01)$. Regression models were adjusted to evaluate variation of these components due to yacon flour supplementation to the yogurt (table 2).

Greater concentrations of solids (ash, total dietary fiber and carbohydrates) for the same amount of product results in a linear reduction of water observed as yacon flour concentration increased. Therefore, a smaller concentration of solids and greater concentration of water was observed in the control yogurt when compared to yogurts with yacon flour.

A proportional growth in ash content was observed as the level of yacon flour added to the yogurt formulations increased in comparison to the control yogurt. This growth may be caused by the higher levels of phosphorus and potassium in the flour, since yacon has significant concentrations of such minerals, $23.4 \mathrm{mg} / 100 \mathrm{~g}$ of phosphorus and $170.7 \mathrm{mg} / 100 \mathrm{~g}$ of potassium (10).

Increase in the addition of yacon flour promoted a slight increase in the amount of IDF, SDF, FOS and inulin in the yogurts.

According to Brazilian regulations, functional foods are those which present at least $1.5 \mathrm{~g}$ of dietary fiber, FOS or inulin in liquid food per ready to eat portion (21). Considering a $200 \mathrm{~mL}$ yogurt portion, none of the yogurts in this study reached the necessary amount of total dietary fiber, FOS and/ or inulin required. However, the yogurts containing more than $2.56 \%$ of yacon flour presented a total dietary fiber content ranging from 2.06 to $2.76 \%$ per portion (table 1), meeting the recommended levels. Therefore, the yogurts containing

\section{TABLE 1}

Mean values and standard deviation for centesimal composition and caloric value of the yogurts added of yacon flour.

\begin{tabular}{|c|c|c|c|c|c|}
\hline $\begin{array}{c}\text { Components } \\
(\%)\end{array}$ & $\begin{array}{l}\text { Control } \\
\text { yogurt }\end{array}$ & $\begin{array}{l}\text { Yogurt with } \\
1.58 \% \text { YF* }\end{array}$ & $\begin{array}{l}\text { Yogurt with } \\
2.56 \% \text { YF* }^{*}\end{array}$ & $\begin{array}{l}\text { Yogurt with } \\
3.00 \% \text { YF* }^{*}\end{array}$ & $\begin{array}{l}\text { Yogurt with } \\
3.86 \% \mathrm{YF}^{*}\end{array}$ \\
\hline Water & $91.11 \pm 0.71$ & $90.55 \pm 0.61$ & $89.73 \pm 0.50$ & $89.43 \pm 0.82$ & $87.62 \pm 0.95$ \\
\hline Proteins & $3.72 \pm 0.15$ & $3.92 \pm 0.39$ & $3.65 \pm 0.11$ & $3.46 \pm 0.09$ & $3.94 \pm 0.16$ \\
\hline Lipids & $0.02 \pm 0.00$ & $0.01 \pm 0.01$ & $0.01 \pm 0.01$ & $0.03 \pm 0.01$ & $0.01 \pm 0.01$ \\
\hline Ashes & $0.70 \pm 0.11$ & $0.85 \pm 0.01$ & $0.87 \pm 0.01$ & $0.81 \pm 0.02$ & $0.91 \pm 0.01$ \\
\hline TDF $^{* *}$ & 0 & 0.70 & 1.03 & 1.11 & 1.38 \\
\hline IDF & 0 & 0.25 & 0.41 & 0.48 & 0.61 \\
\hline SDF & 0 & 0.04 & 0.06 & 0.07 & 0.09 \\
\hline FOS & 0 & 0.14 & 0.17 & 0.17 & 0.20 \\
\hline Inulin & 0 & 0.27 & 0.39 & 0.39 & 0.48 \\
\hline Carbohydrates & 4.45 & 3.97 & 4.71 & 5.16 & 6.14 \\
\hline Caloric value $e^{* * *}$ & 32.9 & 31.7 & 33.5 & 34.8 & 40.4 \\
\hline
\end{tabular}


more than $2.56 \%$ of yacon flour may be considered sources of total dietary fiber claimed to be functional.

Values of total dietary fiber, FOS and inulin in the yogurts (determined through the enzymatic-gravimetric and HPLC methods) were lower than expected. This may be due to the enzymatic degradation of FOS and inulin into sucrose, fructose and glucose which occurs during storage of yacon flour (21), since the yacon used in the production of the yogurt was stored in refrigerators (at $10^{\circ} \mathrm{C}$ ) for seven months.

It is also noticeable that the amount of carbohydrates in the yogurt tends to decrease when yacon flour is added, presenting minimum levels when the yogurt contains $1.1 \%$ yacon flour. The yogurts with less addition of yacon flour presented a slight reduction in water content and an increase in total dietary fiber compared to the control yogurt. This fact is rather justifiable because, the same quantity of yogurt presents a reduction in the level of carbohydrates, something that asks for the definition of a quadratic effect to account for such behavior. Bearing this in mind, it is justified that the same quantity of yogurt presents a reduced level of carbohydrates, something that requires the definition of a quadratic effect to account for such behavior (table 2). Since the difference in water content between the yogurts with more than $1.1 \%$ yacon flour and the control yogurt is high, a growing level of carbohydrates can be observed following the increase of yacon flour concentration.

The caloric value ranged from 31.7 to $40.4 \mathrm{kcal} / 100 \mathrm{~g}$ of yogurt. This is lower than value defined by the Brazilian Table of Food Composition (TACO, 23), in which skim yogurt provides $41 \mathrm{kcal} / 100 \mathrm{~g}$ of the product. The caloric value in this study was calculated based on protein, lipid and carbohydrate contents. Protein and lipid content did not present significant variations ( $p>0.01)$ among the studied yogurts. The increase in caloric value may be due to the change in carbohydrate content in the yacon flour. Results suggest that the addition of yacon flour to yogurt has little effect on the caloric value. Moreover, the product has increased level of dietary fiber which may cause a slower absorption of carbohydrates in the intestinal tract.

Results of yogurt physicochemical analysis

Results observed for the yogurt $L^{*}, a^{*}$ and $b^{*}$ color space coordinates, $\mathrm{pH}$ values, total soluble solids (TSS) and acidity are shown in table 3.

Analysis of variance showed that yogurts differed significantly $(p<0.01)$ in $L^{*}, a^{*}$ and $b^{*}$ color values, TSS and acidity. The $\mathrm{pH}$ did not change significantly $(p>0.01)$ as the amount of yacon flour added to the yogurt increased. Average $\mathrm{pH}$ values for all five yogurts was 4.49 with mean values ranging from 4.28 to 4.69 (table 3). This is in agreement with Brazilian regulations which suggest a $\mathrm{pH}$ value of 4.5 for fermented milk

TABLE 2

Regression equations for the variation of the water content, ash, IDF, SDF, FOS and inulin due to yacon flour addition (X) and their respective coefficient of determination $\left(R^{2}\right)$ and probability value for the regression model $F$.

\begin{tabular}{lccc}
\hline Component & Linear regression models & $R^{2}$ & Prob $>\mathrm{F}$ \\
Water & $0.91-0.01 \mathrm{X}$ & 0.84 & $<0.0001$ \\
Ashes & $0.73+0.05 \mathrm{X}$ & 0.77 & 0.0404 \\
IDF & $0.1591 \mathrm{X}$ & 0.99 & $<0.0001$ \\
SDF & $0.02 \mathrm{X}$ & 0.99 & $<0.0001$ \\
FOS & $0.02+0.05 \mathrm{X}$ & 0.91 & $<0.0001$ \\
Inulin & $0.03+0.12 \mathrm{X}$ & 0.96 & $<0.0001$ \\
Carbohydrates & $4.41-0.64 \mathrm{X}+0.29 \mathrm{X}^{2}$ & 0.99 & $<0.0001$ \\
\hline $\mathrm{X}=\%$ of Yacon flour & & &
\end{tabular}

\section{TABLE 3}

Mean values and standard deviation of the $\mathrm{L}^{*}, \mathrm{a}^{*}$ and $\mathrm{b}^{*}$ coordinates, $\mathrm{pH}$, total soluble solids and acidity of the yogurts added of yacon flour.

\begin{tabular}{|c|c|c|c|c|c|c|}
\hline \multicolumn{2}{|c|}{ Parameters } & Control & Yogurt with & Yogurt with & Yogurt with & Yogurt with \\
\hline \multirow[t]{3}{*}{ Color } & $\mathrm{L}^{*}$ & $76.03 \pm 1.68$ & $74.97 \pm 0.21$ & $72.73 \pm 0.29$ & $71.93 \pm 0.21$ & $67.77 \pm 1.69$ \\
\hline & $a^{*}$ & $1.3 \pm 0.17$ & $1.87 \pm 0.15$ & $2.23 \pm 0.11$ & $2.37 \pm 0.21$ & $1.83 \pm 0.15$ \\
\hline & $b^{*}$ & $14.37 \pm 0.11$ & $17.57 \pm 0.21$ & $18.43 \pm 0.30$ & $18.23 \pm 0.21$ & $17.2 \pm 0.17$ \\
\hline $\mathrm{pH}$ & & $4.28 \pm 0.03$ & $4.28 \pm 0.08$ & $4.69 \pm 0.35$ & $4.54 \pm 0.01$ & $4.68 \pm 0.01$ \\
\hline TSS** & & $7.33 \pm 0.30$ & $8.57 \pm 0.30$ & $9.67 \pm 0.06$ & $9.73 \pm 0.29$ & $11.8 \pm 0.00$ \\
\hline Acidity & & $86 \pm 0.49$ & $97 \pm 0.14$ & $95 \pm 0.28$ & $77 \pm 0.14$ & $76 \pm 0.00$ \\
\hline
\end{tabular}

* Yacon flour; ** Total soluble solids

The average and the standard deviation were obtained based on the results of 2 repetitions of each yogurt sample. 
products, including yogurt. Yogurts with $\mathrm{pH}$ values lower may be rejected by consumers and would favor coagulation due to reduction of proteins and lead to whey separation. Values of $\mathrm{pH}$ higher than 4.6 may also result in whey separation since the gel is not formed (24).

Regression equations were adjusted $(p<0.01)$ for $L A B$ color coordinates and for TSS and acidity values, table 4.

A regression analysis showed a linear effect of yacon flour supplementation on $L^{*}$ values. The quadratic model fitted best for $a^{*}$ and $b^{*}$ values. Reduction of $L^{*}$ values with increase in the amount of yacon flour indicated darkening of the yogurts. This may result from coloring of flour, which happens due to enzymatic browning reactions by the presence of phenolic compounds (4), and non-enzymatic browning during yogurt processing. However, all yogurts may be considered lightcolored, since on a scale ranging from 0 to 100 , they presented values over $50\left(L^{*}>50\right)(25)$.

The $a^{*}$ and $b^{*}$ values were in the red and yellow regions, respectively, since readings were on the positive side of the scale, with higher intensity for yogurts with 2.5 and $2.6 \%$ of yacon flour. This indicates that the combination of the positive $a^{*}$ and $b^{*}$ chromes results in a brown color. Total soluble solids (TSS) contents increased linearly with addition of yacon flour to the yogurt. This may be linked to the higher level of fructans (FOS and inulin) in the yogurts with higher concentrations of yacon flour.

A quadratic model was chosen to explain acidity variation with yacon flour supplemented yogurt. It is observed that yogurts containing $1.4 \%$ yacon flour presented acidity levels (table 4). This accounts for the growing reduction of the acidity with increase in yacon flour concentration; and may also be related to the increased amount of TSS (table 3 ), since there is a strong inverse relation between TSS and acidity (26).

\section{Results of apparent viscosity measurement of the yogurts}

Yogurts with yacon presented a shear-thinning fluid behavior, i.e., their apparent viscosity decreased as the shear rate increased. This reduced gumminess during intake (27).

The control yogurt presented a higher apparent viscosity than the yogurt with $1.58 \%$ yacon flour, both at $10{ }^{\circ} \mathrm{C}$ and $25^{\circ} \mathrm{C}$, as can be seen in figure 1 .

The apparent viscosity of yogurts evaluated at $25^{\circ} \mathrm{C}$ was lower than that at $10^{\circ} \mathrm{C}$. This behavior is quite common in food fluids (28) since increase in temperature promotes a decrease in viscosity. This occurs because the movement of suspended particles increases (29).

These apparent viscosity variations due to the addition of yacon flour were significant $(p<0.01)$ for the yogurts at both temperatures, $10{ }^{\circ} \mathrm{C}$ and $25^{\circ} \mathrm{C}$, making it possible to adjust models to predict this behavior, as can be seen in Table 5 .

As expected, when taking into account the lower apparent viscosity of yogurt with $1.58 \%$ yacon flour when compared to control, variation of apparent viscosity at both temperatures generated quadratic equations, with a high coefficient of determination ( $R^{2}>90 \%$ ).

FOS and inulin are soluble dietary fibers capable of interacting with the aqueous portion of the yogurt. They are highly hygroscopic substances which act as food stabilizers because of their capability to form a more cohesive mesh, similar to gel (30), thus changing system viscosity. Despite this, these products are not able to form a gel after heating and cooling processes at some concentrations (31). Therefore, it is suggested that the FOS and inulin content in yogurts with $1.1 \%$ and $0.85 \%$ yacon flour may have been insufficient to form gel and increase product viscosity at temperatures of $10^{\circ} \mathrm{C}$ and $25^{\circ} \mathrm{C}$.

Additionally, yogurt carbohydrate levels also have an influence on product apparent viscosity, and carbohydrate content also presented a quadratic effect due to yacon flour concentration, corroborating the quadratic regression model adjusted for apparent viscosity.

\section{CONCLUSION}

Addition of yacon flour to yogurt leads to products with low fat and low caloric values. Yogurts supplemented with 2.56 $\%$ to $3.86 \%$ yacon flour may be considered prebiotics. They were capable of providing dietary fiber concentrations higher than the minimum recommended by Brazilian regulations.

It was not possible, however, to obtain yogurts considered source of FOS and inulin as expected. Further studies are needed in order to optimize the use of even greater yacon concentrations in food products given the notable benefits it can bring to consumers.

\section{RESUMEN}

La harina de yacón se ha utilizado en muchos productos alimenticios, debido a su alto contenido de fructooligosacáridos y inulina, compuestos que tienen propiedades promotoras de la salud. En este estudio, la harina de yacón fue utilizada como ingrediente en yogur "light" en las siguientes concentraciones: $1,58,2,56,3,00$ y 3,86\%. Se determinaron la composición centesimal, $\mathrm{pH}$, sólidos solubles, acidez y la viscosidad

\section{TABLE 4}

Regression equations for the variation of the $L^{*}, a^{*} e b^{*}$ color space coordinates, total soluble solids and acidity according to the concentration of the yacon flour $(X)$ and their respective coefficient of determination $\left(R^{2}\right)$ and probability value for the regression model $F$.

\begin{tabular}{|c|c|c|c|c|}
\hline \multicolumn{2}{|c|}{ Parameters } & Linear regression models & $\mathrm{R} 2$ & Prob $>\mathrm{F}$ \\
\hline \multirow[t]{3}{*}{ Color } & $L^{*}$ & $77.09-2.00 x$ & 0.78 & $<0.0001$ \\
\hline & $a^{*}$ & $1.25+0.74 X-0.14 X^{2}$ & 0.77 & 0.0001 \\
\hline & $b^{*}$ & $14.33+3.11 X-061 X^{2}$ & 0.98 & $<0.0001$ \\
\hline TSS** & & $7.05+1.07 X$ & 0.91 & $<0.0001$ \\
\hline Acidity & & $87.30+10.77 X-3.75 X^{2}$ & 0.70 & 0.0015 \\
\hline
\end{tabular}


del yogur suplementado con yacón se determinaron. Los resultados fueron evaluados mediante un análisis de varianza y de regresión. La composición centesimal de los yogures permite que los clasifiquen como alimentos bajos en grasa, con bajo contenido de carbohidratos y que contenga fibra dietética, particularmente aquellos suplementados con más de 2,56\% de harina de yacón, que puede considerarse como fuente de fibra y, en consecuencia, prebióticos. El análisis físico-químico reveló cambios significativos $(p<0,05)$ en el análisis de color, sólidos solubles, viscosidad y acidez a temperaturas de 10 y $25^{\circ} \mathrm{C}$ con la harina de yacón en aumento.

Palabras clave: fructooligosacáridos, inulina, prebióticos, yogur, yacón.

\section{REFERENCES}

1. Stringheta $P C$, Oliveira $T T$, Gomes $R C$, Amaral $M P H$, Carvalho A F, Vilela M A P. Políticas de saúde e alegações de propriedades funcionais e de saúde para alimentos no Brasil. Rev Bras Cienc Farm 2007;43(2):181-194

2. Roberfroid $M B$. Concept in functional foods: the case of inulin and oligofructose. J Nutr 1999;129:1398-401.
3. Gibson $G R$, Roberfroid $M$. Dietary modulation of the human colonic microbiota: introducing the concept of prebiotics. J Nutr 1995;125:1401-12.

4. Seminario J, Valderrama M, Manrique I. El yacon: fundamentos para el aprovechamiento de un recurso promisorio. Centro Internacional de la Papa (CIP), Universidad Nacional de Cajamarca, Agencia Suiza para el Desarrollo y la Cooperación (COSUDE), Lima, Peru. 2003.

5. Meier R, Lochs H. [Pre- and probiotics]. Ther umsch 2007; 64(3):161-9.

6. Rolim PM, Salgado S M, Padilha V M, Livera A V S, Guerra N B, Andrade S A C. (2010). Análise de componentes principais de pães de forma formulados com farinha de yacon (Smallanthus sonchifolius (Poepp.) H. Rob.). Rev Ceres;57(1):12-7.

7. Rosa C S, Oliveira V R, Vieira V B, Gressler C, Viega S. Elaboração de bolo com farinha de Yacon. Cienc Rural 2009;39(6):1869-72.

8. Búrigo $T$, Fagundes $R L N$, Trindade E B S M, Vasconcelos $H$ C F F. Efeito bifidogênico do frutooligossacarídeo na microbiota intestinal de pacientes com neoplasia hematológica.

\section{FIGURE 1}

Variation of the apparent viscosity of the yogurts containing 0\%, $1.58 \%, 2.56 \%, 3.00 \%$ and $3.86 \%$ of yacon flour at the temperatures of $3 / 4$ ?] $3 / 410{ }^{\circ} \mathrm{C}$ and $3 / 4$ ? $3 / 425^{\circ} \mathrm{C}$.

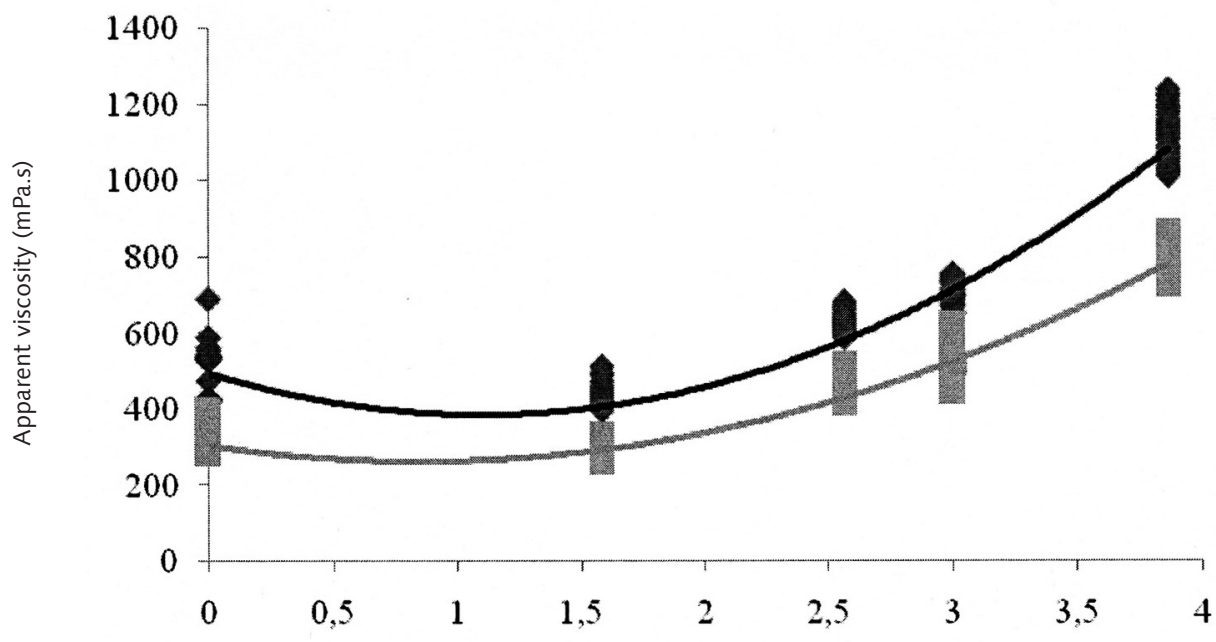

Yacon flour concentration

TABLE 5

Regression equations for variation of viscosity of yogurts with yacon flour at 10 and $25^{\circ} \mathrm{C}$ due to concentration of yacon flour $(X)$ with their respective coefficients of determination $\left(\mathrm{R}^{2}\right)$ and probability of $F$ value for the regression model.

Temperature

$10^{\circ} \mathrm{C}$

$25^{\circ} \mathrm{C}$

$$
\text { Linear regression model }
$$

$495.85-199.26 X+90.78 X^{2}$

$305.49-97.13 X+57.08 X^{2}$

\section{R2 Prob $>F$}

$0.94 \quad 0.0020$

$0.99<0.0001$ 
Rev Nutrição 2007; 20(5):491-7.

9. Brasil. Alimentos com Alegações de Propriedades Funcionais e ou de Saúde, Novos Alimentos/Ingredientes, Substâncias Bioativas e Probióticos. IX - Lista das Alegações Aprovadas. Agência Nacional de Vigilância Sanitária - ANVISA. 2005. Available in: http://wwW.anvisa.gov.br/alimentos/comissoes/tecno_lista_alega.htm. Acess in: june 21, 2011.

10. Ribeiro J A P, Barcelos M F P, Angelis-Pere M C, Ferreira $E$ B. Estudo da influência do consumo de yacon sobre os níveis glicêmicos de ratos. $11^{\circ}$ Congresso Nacional da SBAN, Fortaleza - CE, 2011; 22:350.

11. Association of Official Agricultural Chemists. Official Methods of Analysis of the AOAC.18. ed. Gaithesburg: Association of Official Analytical Chemists. 2002.

12. Association of Official Agricultural Chemists. Official Methods of Analysis of the AOAC. 16th ed. Gaithesburg, 1997.

13. Kaneko T, Kudo T, Horikoshi K. Comparasion of CD composition produced by chimeric Cgtases. Agric Biol Chem 1990;54(1):197-201.

14. Watt $B$, Mirrill A L. Composition of foods: raw, processed, prepared. 8. ed. Washington: Consumer and Food Economics Research Divisions/Agricultural Research Service. 1963.

15. Granato $D$, Masson $M L$. Instrumental color and sensory acceptance of soy-based emulsions: a response surface approach. Ciên Tecnol Aliment 2010;30(4): 1090-6.

16. Instituto Adolfo Lutz. Métodos químicos e físicos para análise de alimentos. 3. ed. São Paulo: IMESP. 1985.

17. Engelen $L$, De Wijk $R A$, Prinz J F, Janssen A M, Weenen $H$, Bosman $F$. The effect of oral and product temperature on the perception of flavor and texture attributes of semisolids. Appet 2003;41:273-81.

18. Gonçalves C F F, Sanches S F, Sharma N K. Métodos lineares nas estimativas dos parâmetros do modelo inteiramente casualizado. Semina 1986; 7(1):27-31.

19. Statistical Analysis System - SAS. User's procedures guide. Version 9.1, Cary: SAS Institute, Inc 1989. $2 \mathrm{v}$.

20. Brasil. Padrões de Identidade e Qualidade (PIQ) de Leites
Fermentados. Ministério da Agricultura, Pecuária e Abastecimento. Secretaria de Defesa Agropecuária. Departamento de Inspeção de Produtos de Origem Animal. Resolução $n^{\circ}$ 5, 13 de novembro de 2000.

21. Brasil. Regulamento técnico referente à informação nutricional complementar. Ministério da Saúde. Diário Oficial da União, Brasília, DF, n. 11E, 4-13. Portaria n. 27, de 13 de janeiro de 1998.

22. Graefe S, Hermann M, Manrique I, Golombek S, Buerkert A. Effects of post-harvest treatments on the carbohydrate composition of yacon roots in the Peruvian Andes. Field Crop Res 2004; 86:157-65.

23. TACO, Tabela Brasileira de Composição de Alimentos. Versão 2. Campinas: Nepa-Unicamp. 2006. Available at: http:// www.unicamp.br/nepa/taco/tabela. php?ativo=tabela. Acess in: june 28, 2011.

24. Brandão S C C. Tecnologia da produção de iogurte. Rev Leite e Derivados 1995; 5(25):24-38.

25. Cohen K O, Jackix M N H. Estudo do licor de cupuaçu. Ciênc Tecnol Aliment 2005;25(1):182-90.

26. Silva $G G$, Morais $P L D$, Rocha $R H C$, Santos $E C$, Sarmento J D A. Caracterização do fruto de cajaranazeira em diferentes estádios de maturação. Rev Bras Prod Agroind 2009;11(2):159-63.

27. Duboc P, Beat M. Applications of exopolysaccharides in the dairy industry. Int Dairy J 2001;11:759-68.

28. Pereira E A, Queiroz A J M, Figuêiredo R M F. Comportamento reológico de mel da abelha uruçu (Melipona scutellaris, L.). Rev Cienc Exatas Nat 2003;5(2):179-86.

29. Vidal J R M B, Sierakowski M R, Haminiuk C W I, Masson M $L$. Propriedades reológicas da polpa de manga centrifugada. Rev Ciênc Agrotec 2006;30(5):955-60.

30. Gel-Nagar G, Clowes G, Tudoricã C M, Kuri V. Rheological quality and stability of yog-ice cream with added inulin. Int J Dairy Technol 2002;55(2):89-93.

31. Kim Y, Faqih M N, Wang S S. Factors affecting gel formation of inulin. Carbohydr Polym 2001;46(2):135-45. 